\title{
The Intertwining Concerns of Libraries and Writing Centers
}

Wesley D. Custer, Asbury Theological Seminary

\begin{abstract}
Through 2020, Asbury Theological Seminary largely built an introductory course for those preparing for graduate-level study in seminary disciplines. Through that work and the collaborative efforts between our research librarian, Writing Center, and instructional designer, we have discovered shared concerns, knowledge, and new insights into how to help our students. Great synergy was found in terms of information literacy, citations, using information well, and a desire to see students/patrons succeed. Points of divergence were found in terms of organizational structures (siloes) and a potential conflict between a "do for" rather than "teach how" staff focus. Recommendations also are given at the close regarding having writing resources available for patrons in contexts where there is not a writing center.
\end{abstract}

\section{INTRODUCTION}

Through 2020, Asbury Theological Seminary largely built an introductory course for those preparing for graduate-level study in seminary disciplines. Through that work and the collaborative efforts between our research librarian, Writing Center, and instructional designer, we have discovered shared concerns, knowledge, and new insights into how to help our students. This presentation will describe the institute course that was developed and the benefits/ insights that came through the process.

\section{BACKGROUND}

Emerging through the Quality Enhancement Plan (QEP) (reported in the 2017 presentation by Tippey, Horner, and Stelle, titled: "Won't You Be My Neighbor: Camaraderie at the Intersection of Research and Writing Services”), Asbury Theological Seminary has been having a growing success with the Writing Center synergizing with the rest 
of our library-based research services (Tippey, Horner, and Stelle 2017). The role of the writing center consultants over the past several years has included the occasional (or perhaps regular) research question, which has been a great benefit to their role, because many of our writing consultants are also excellent researchers. We seem to be discovering that quality writing is closely correlated to quality research skills. This program has seen good success over the years and is poised to work on continuing forward-looking improvements.

In 2018, the area of Library Services joined with Information Technology forming a combined Library, Information, and Technology Services department. This resulted in a significant restructure, centralizing research services, circulation, reference, basic technology help, instructional design, and instructional technology under a new heading of Instructional Services. The work of research services now rests with the Director of Instructional Services, who also supervises our Instructional Design and Technology department along with the Help Desk and provides online/digital librarianship.

\section{REASON FOR THE COURSE AND THE TEAM}

With a new structure in place and a Writing Center well established, the Enrolment Management Team (EMT) requested an institute-style course to give the rejected applicant an opportunity to develop some skills and prove their ability to succeed in graduate education. This newly collaborative structure has been very helpful for thinking through this course and building it in Canvas, our Learning Management System. We put together a team to develop the course made of our Instructional Designer, Joelene Goh, Director of the Writing Center, Dr. Ginger Stelle, and myself as the Director of Instructional Services. We spent the early stages of the development determining what incoming students would most benefit from knowing prior to matriculation. We determined that it would be best if we could introduce the student to foundational information literacy, solid writing principles, and critical thinking skills.

\section{POINTS OF WRITING CENTER AND RESEARCH/REFERENCE LIBRARIANSHIP OVERLAP}

The first point of overlap and synergy is in information literacy. It is a core concept that good writing requires good information and 
finding good information requires a foundation of information literacy. Writing centers are heavily invested in the student having the right information to support their claim in writing. That gives the writer the content for their argument, and without good information a paper cannot be anything but personal reflection or opinion. Academic librarians are also deeply invested in patrons finding the best information in the best manner possible. We live in the world of information discovery, access, and evaluation for the purpose of supporting academic achievement.

The second point of synergy is in the use of citations in writing. Citations are a key part of using information well, which has always been a core value of librarians - and academic librarians in particular. Writing centers tend to be citation format gurus for the student/ patron. Academic librarians have also filled this role in the absence of writing centers. There is ample potential for collaboration and information-sharing along these lines.

The third area of synergy, citation management software, is also a major concern and area of expertise for both the academic librarian and the writing center. While citation software is a bit of an extension of good citation practice, the use of software is a unique skill. Academic librarians have been using Zotero or other citation programs for years, and writing centers have been places where students would learn about citation management also.

Fourthly, having already mentioned using information well, we should point to that as a unique point of synergy. Academic librarians are always concerned about using information well, particularly from an information literacy standpoint. Writing centers take it a bit farther in the mechanics of expression in writing. This can also include argumentation development and document structure. I find that research appointments occasionally wander into argumentation or document structure depending on the needs of the student. We will talk about some recommendations later to assist in the absence of a writing center.

Lastly, a common theme through all of these points of synergy is the basic desire to see our students and patrons succeed academically in their work. This may go without saying but I will say it anyway. Academic librarians are deeply desirous that their patrons do well in their academic work. This success sheds light onto the value of our profession. Likewise, writing centers also are deeply invested in the academic success of their clients because their exis- 
tence may be evaluated by the overall academic success and/or writing quality of their clients.

There are many ways, as we have discussed, in which academic librarians and writing centers are similar and synergistic in their focus and goals. There are also ways in which conflict may arise or our goals/methods may be divergent.

\section{POINTS OF DIVERGENCE OR POTENTIAL CONFLICT}

It may be that a writing center lives in your library space but does not have unified oversight. In my context, the Writing Center reports to the Dean of Library, Information, and Technology Services the same as I do. This allows for a unified overarching vision for our larger department, and we can coordinate on training and refer patrons back and forth. In other contexts, the reporting structure could go to student services and not in an academic authority structure, causing significant differences in focus, goals, or support methods. Be conscious of this.

If your institution starts a writing center, it could be seen as the golden child where the library becomes the old-school folks in the institution. If you have any influence or voice while a writing center gets launched in your institution, work early on to partner with them and be involved regardless of the reporting structure. While the writing center will still be the "new kids" in the institution, they do not have to be an adversary or make the librarians the old guard or something.

Good working relationships require conversation, and the basic organizational structure of your institution may prevent or hinder good conversation. There is a tendency of any structure to become siloed and isolated from others in the organization. Many times, the organizational structure as mentioned before can play a significant role in hindering collaboration and conversation. Writing centers need to have a good working relationship with the librarians, and it may be up to the librarians to foster that relationship.

Many writing centers will be noisier places where food and drink are welcomed and encouraged. Libraries tend to not be those spaces. When space is shared, this will cause some points of tension and potentially significant conflict as noise and food find their way into the rest of the facility. Students may find themselves frustrated by the noise coming from a writing center. They may also be frustrated that 
they cannot bring their food into the rest of the library. Again, fostering good working relationships with the leadership of both entities will allow for better resolution as these conflicts arise.

Operating hours may be significantly different. Likely the library will have more extended hours than the writing center or vice versa. One is not likely better than the other, but complaint from patrons regarding one or the other regarding hours will always occur. It does not matter how many hours each service provides; it will always be wrong to someone.

A major core difference may be that the writing center is focused on teaching how to write, revise, etc., and will never do the work for the student. Libraries, on the other hand, are more likely to be the place to have your information handed to you rather than to be taught how to find information. To put this a different way, a writing center may be a training program where a library may be a mere search engine-or worse, a search assistant. I work very hard to make our normal operating procedure in our library interactions follow a show-help-let process. Our patrons do not always come wanting to learn, but it can be very natural to show them how to accomplish their task, help them do it, and then let them do it on their own from then on. This does not mean that they will not ask again or need to be shown or helped multiple times, because skill acquisition requires repetition. Students who go to the writing center are more likely to enter a more structured instructional interaction, and their expectation is more likely aligned with that modality.

\section{RECOMMENDATIONS}

Avoid the "we've always done it this way" trap. Some traditions are good, but we need to be more adaptable. Embrace new ideas, perhaps embrace them critically, but embrace them all the same. Resist the desire to entrench rather than engage in conversation.

Have resources on writing available for your patrons. There is a plethora of sites and resources available. For those of us who do not have access to a writing center or even additional librarians to assist with these tasks, it can go a long way in helping to point students to good resources on writing and writing related topics.

Seek out the guidelines or manuals from writing centers. It is not difficult to search the web for writing center training manuals or interaction guidelines. Having a familiarity with what they do and 
their methods may help us librarians think through our practices and help us guide students in better writing as well.

Develop a list of paid proofreaders/copyeditors to hand out to patrons. There will always be those whose needs are preparing for publication rather than a simple term paper. For them, they need to pay a proofreader or copyeditor. Have a list of resources for them too.

\section{A FINAL FRIENDLY WARNING}

Theological librarians are uniquely equipped to enter the writing center services arena, but only do so if it advances your core mission, not because you are trying to prove your worth to your administration. Let librarianship stand on its own, and maybe increase your services where it makes sense in your context.

\section{BIBLIOGRAPHY}

Tippey, Paul A, Thad Horner, and Ginger Stelle. 2017. “'Won’t You Be My Neighbor': Camaraderie at the Intersection of Research and Writing Services.” ATLA Summary of Proceedings 71: 196-99.

\section{FURTHER READING}

Hurvitz, Tate, Roxane Benvau, and Megan Parry. 2015. “Collaborative Approaches to Deepen Student Learning: Information Literacy, Curriculum Design, and Student Learning Workshops.” Learning Communities: Research \& Practice 3 (1). https://eric. ed.gov/?id=EJ1112526.

Zauha, Janelle. 2014. "Peering into the Writing Center: Information Literacy as a Collaborative Conversation." Communications in Information Literacy 8 (1): 1-6. 